\title{
Tree species of South America central savanna: endemism, marginal areas and the relationship with other biomes
}

\author{
Renata D. Françoso ${ }^{1 \star}$, Ricardo F. Haidar ${ }^{2}$ and Ricardo B. Machado ${ }^{1}$
}

Received: September 16, 2015

Accepted: November 5, 2015

\begin{abstract}
Biological knowledge is important for guidance of conservation polices. In the Cerrado, an extremely diverse biome, the last synthesis of floristic knowledge has more than ten years. To understand the progress on the information, our aim was quantify the tree species of the Cerrado, and assess their distribution. We compiled 167 inventories and rapid surveys of tree species, corresponding to 625 sites. We accessed the species distributions in the Brazilian biomes, and estimated the number of species in the savannas of Cerrado using four algorithms. We observed a greater local richness in more central regions of the biome, but due to high beta diversity, more peripheral regions presented a greater cumulative richness. The Atlantic Forest was the most important neighbouring biome, influencing the floristic composition of the Cerrado. The proportion of typical Cerrado species was $16 \%$. The highest proportion of endemic species is possibly found in other life forms, and it is crucial that these species are included in inventories and floristic surveys. To guide new studies and help supplement the knowledge of the Cerrado's flora, we identified the main sampling gaps, located mainly in ecotonal regions, which are responsible for the largest number of species recorded in studies of the Cerrado.
\end{abstract}

Keywords: Brazilian flora, Cerrado, endemic species, floristic patterns, South America, species distribution

\section{Introduction}

The occurrence of a certain taxon in a location and in a given period of time is the most elemental biological information (Sousa-Baena et al. 2014), and is crucial to the study, management, and conservation of biodiversity (Boulinier et al. 1998). During the last few decades, several studies have synthesized the knowledge available on the Cerrado (Rizzini 1963; Heringer et al. 1977; Ratter \& Dargie 1992; Castro et al. 1999; Oliveira-Filho \& Ratter 2002; Ratter et al. 2003), a savanna-like biome. The term biome is here applied as suggested by Clements \& Shelford (1939), being a complex of organisms, including the climax vegetation and its subdivisions, and also the fauna, occupying large areas under the same climatic domain.
In that way, we are considering as the Cerrado (in capital letter), all the extension delimited by IBGE (2004) and the small enclaves in other biomes. These studies have focused on the tree species of cerrado lato sensu, which includes fields, savannas and the wood savannas. This is the main vegetation across the Cerrado (Coutinho 2006). The first estimative mentioned 400 tree species in the Cerrado (Rizzini 1963). These numbers subsequently increased to around 700 species (Heringer et al. 1977; Ratter \& Dargie 1992) and 951 species (Ratter et al. 2003; Bridgewater et al. 2004). The Cerrado was estimated to harbour between 1,000 and 2,000 species of trees and shrubs combined (Castro et al. 1999). This number corresponds to more than $11 \%$ of the Cerrado's biodiversity (Mendonça et al. 2008), which makes this group highly relevant to the understanding of the biome's patterns

\footnotetext{
${ }^{1}$ Departamento de Zoologia, Instituto de Ciências Biológicas, Universidade de Brasília, Brasília, Distrito Federal, Brazil

2 Programa de Pós-graduação em Ecologia da Universidade de Brasília, Campus Universitário Darcy Ribeiro, 70910-900, Brasília, DF, Brazil

* Corresponding author: renatafrancoso@yahoo.com.br
} 
and processes. In addition, vegetation has a major role in acting as a biodiversity surrogate when there is little data available for other taxonomic groups (Lombard et al. 2003; Oliver et al. 2004; Di Minin \& Moilanen 2014; but see Stoms et al. 2005).

The high floristic diversity and heterogeneity observed in the Cerrado is explained by biotic and abiotic factors, such as edaphic distinctions between regions and fire frequency, as well as by stochastic factors (Ratter \& Dargie 1992; Batalha \& Martins 2007). For these and other reasons, there is a high beta diversity of plants in the Cerrado (Felfili et al. 1994; Oliveira-Filho \& Ratter 2002; Ratter et al. 2003; Bridgewater et al. 2004; Felfili \& Silva-Júnior 2005). Marginal regions contribute greatly to this pattern (Rizzini 1963; Castro et al. 1999) by strongly influencing the biogeographical patterns of the biome (Machado et al. 2008). This influence occurs due to the occasional presence of so-called accessory species, derived predominantly from other biomes (Rizzini 1963; Heringer et al. 1977).

The Cerrado shares several genera and species with the Atlantic Forest and the Amazon (Méio et al. 2003; Bridgewater et al. 2004). The influence of the Atlantic Forest is significantly greater than that of the Amazon (Rizzini 1963), probably due to a higher tolerance of the species to low temperatures (Méio et al. 2003). However, it is not precisely known how the shared species are distributed between the Cerrado and the adjacent biomes. Because of this external influence, most characteristic Cerrado formations must probably be found in the central portion of the biome (Castro et al. 1999), where endemic and Typical Cerrado Species (TCS) are likely to occur. We consider the species limited to the Cerrado biome as endemic, and species largely distributed along the Cerrado, but with some records in other biomes, as TCS.

Endemic plant species represent $44 \%$ of the total number of species listed for the biome, including all habits and formations (Myers et al. 2000). The proportion of endemic species of cerrado is not exactly known. However, it is estimated that only seven genera are exclusive to the Cerrado, even though 226 species are considered typical of the biome by Rizzini (1963). When only considering the most frequent predominantly cerrado species, 107 species, corresponding to $34 \%$, were observed by Bridgewater et al. (2004).

Not all species observed in the cerrado are predominantly from this environment, and there is a lot of interchange of species among Cerrado physiognomies. There are several examples of congeneric species shared between gallery forests and cerrado (Hoffmann \& Silva-Júnior 2005), and also between dry forests and cerrado (Silva et al. 2010). This continuous fluctuation of species at the edges between forests and savannas formations (Silva et al. 2008) suggests that there have been bi-directional colonization events by forest and savanna species throughout evolutionary history (Forni-Martins \& Martins 2000). These fluctuations are gradual and continuous, and in the ecological time frame, represent the occasional occurrence of species from a certain formation in another, to which the species is less tolerant. It is thus often difficult to determine a species main habitat.

Despite its biological importance, knowledge of biodiversity is often superficial (Sousa-Baena et al. 2014), which leads conservation policies to be guided by incomplete biological information, as much from a taxonomic (Linnean shortfall) as from a biogeographical point of view (Wallacean shortfall) (Lomolino et al. 2006). In a general way, sampling efforts are biased towards certain taxonomic groups and regions that are close to research centres, while little or no effort is made to study other regions (SousaBaena et al. 2014). Even considering the same taxonomic group, such as plants, there are big differences in sampling effort between trees, and herbs or shrubs (Amaral 2015). To improve the biological knowledge currently available, it is necessary to optimize sampling efforts, due to a lack of financial and human resources.

In spite of the inventories available for the woody species in the Cerrado, information gaps still remain (Sousa-Baena et al. 2014). Information obtained from these regions can be extremely valuable in understanding historical and biological processes, since they contribute greatly to the biome's heterogeneity and present an intense interchange of species between neighbouring biomes (Silva \& Bates 2002).

We aimed to increase the biological knowledge of the Cerrado tree species by compiling and synthesizing floristic and phytosociological studies, after more than ten years since the last compilation. Moreover, we provided new information about the number of species and their geographical distributions across the Brazilian biomes, and identified the main information gaps within this group.

\section{Materials and methods}

\section{Study area}

The Cerrado is a large biome in Brazil that spans over more than 2,000,000 $\mathrm{Km}^{2}$ (IBGE 2004), an area equivalent to the size of Portugal, Spain, France, The Netherlands, Belgium, Luxembourg, Italy, Germany, Switzerland, and the Czech Republic, all combined. It occupies the central portion of Brazil, with additional enclaves in the Amazon, Caatinga, and Atlantic Forest. It is composed of three types of formations, based on structural aspects of the vegetation: grassland, savanna, and forest (Eiten 1972; Ribeiro $\&$ Walter 2008). The cerrado lato sensu encompasses a gradient of savanna-like formations ranging from open grasslands to the cerradão (Ribeiro \& Walter 2008). Despite having aspects of a forest, the cerradão is floristically similar to the savannas (Ribeiro \& Walter 2008). Our analyses 
were focused in localities occupied by the cerrado lato sensu (Ribeiro \& Walter 2008), which are henceforth mentioned simply as the cerrado (lower case), throughout the range of the biome, including enclaves within other biomes.

\section{Data compilation and sampling}

We performed a search for floristic and phytosociological studies of cerrado woody species in the CAPES Scientific Journals (a Brazilian system for searches in indexed journals), Web of Science, and the CAPES Thesis and Dissertations database from several Universities, with many keyword combinations in Portuguese, as well as with the corresponding terms in English: cerrado, savanna, floristic, phytosociology, phenology, trees, woody, vegetation, and inventory. Moreover, we used the compilation done by Ratter et al. (2011) as a starting point and the forest inventory of the state of Tocantins (Haidar et al. 2013), together with unpublished studies.

In order to fill the information gaps in the Cerrado, we conducted systematic inventories in Bahia, Maranhão, and Mato Grosso States, following the manual on permanent plots for the Cerrado and Pantanal (Felfili et al. 2005a), and using an adaptation of the "quick survey" method (Ratter \& Dargie 1992; Walter \& Guarino 2006) which consists of walking along a transect in the sampling area, while registering all woody species present during 15-minute intervals, until there were no new species found in a whole interval. Walter \& Guarino (2006) adopted five-minute intervals and concluded that 40 minutes would suffice to include a great number of species and proved to be just as efficient as the plot method for recording species. The maximum distance covered by the authors was $831 \mathrm{~m}$. To assure sampling success, the quick survey was adapted for long distances, using a path length of $1,000 \mathrm{~m}$ in each transect.

\section{Database characterization}

The taxonomy and nomenclature of the species were up to date according to the APG III in Flora do Brasil Species List database (http://floradobrasil.jbrj.gov.br/), where we also obtained information on life-forms. This was a crucial stage in compiling the data, since our database was built using data obtained from different types of methods and sampling criteria. Only those species that were indicated as "trees" were considered, such that several species included previously by Ratter et al. (2003) in floristic surveys were not listed in our study. Unidentified species were also excluded from the database.

To determine the biome or biomes in which a species predominantly occurred, we used the geographic coordinates presented in herbariums, obtained on the SpeciesLink website (http://splink.cria.org.br) for each species in our database, after a careful filtering of the records. At the end of the compilation, we generated a database with ap- proximately 300,000 georeferenced records. These points were overlaid on a grid consisting of 1,000,000 hectares of hexagonal cells, which were in turn classified according to the biome where they were located, according to IBGE (2004). For each species, we calculated the proportion of hexagons present in each biome, disregarding the biomes with less than $20 \%$ of species occurrence, what we considered a safe error margin to not include species with marginal occurrence, or eventual unnoticed mistakes in the herbarium database. We compared the TCS with species restricted to the Cerrado biome based on the Flora do Brasil Species List, in order to arrive at a more conservative definition of Cerrado endemic species. To examine the locations in which most shared species occurred, we built a map of the observed richness of these species. To identify sampling gaps and direct future studies, we built a map with the number of studies per hexagon. We have chosen not to use the Flora do Brasil Species List distributional data as a starting point, since there are still many gaps of species occurrence. We understand that large amount of work takes time to be concluded, despite the great effort that have been done by Flora do Brasil group and by the taxonomic experts. All mapping and spatial analyses were performed in ArcGIS 10 (ESRI 2011).

\section{Results}

We compiled 167 studies (Tab. S1 in supplementary material), from 625 localities, where we identified 907 tree species (Tab. S2 in supplementary material), distributed in 298 genera and 76 families. The most representative families in terms of species number were Fabaceae $(n=144)$, Myrtaceae $(n=84)$, Melastomataceae $(n=46)$, Lauracea $(n=39)$, and Rubiaceae $(n=37)$. The families with greater numbers of genera were Fabaceae $(n=58)$ and Rubiaceae $(n=23)$. Families with only one genus were also common (30 families). In terms of overall frequency, the families Fabaceae, Vochysiaceae, Malpiguiaceae, Bignoniaceae, Apocynaceae, Myrtaceae, Rubiaceae, and Annonaceae were present on more than $80 \%$ of the localities, in this order of importance.

The richest genera, in terms of species numbers, were Miconia $(\mathrm{n}=27)$, Myrcia $(\mathrm{n}=23)$, Eugenia $(\mathrm{n}=22)$, and Byrsonima $(\mathrm{n}=19)$. One hundred and fifty genera were represented by a single species. Out of the 907-recorded species, 249 were represented by a single record in our database, and only 154 occurred in more than $10 \%$ of the localities. The most frequent species, which occurred in 65 to $85 \%$ of the localities, were Qualea grandiflora, Q.parvifolia, Bowdichia virgilioides, Hymenaea stigonocarpa, Connarus suberosus, Byrsonima coccolobifolia, Dimorphandra mollis, and Handroanthus ochraceus. We found one hundred dominant species (Tab. S2 in supplementary material) that are those present in at least 20\% of the sites (Bridgewater et al. 2004). 
The number of tree species recorded per survey varied from five to $158(60 \pm 25)$, and the number of TCS ranged between 0 and $60(24 \pm 12)$ in each locality. The mean number of families recorded per locality was $28( \pm 8)$, while the lowest number recorded was four, and the highest number was 52 families in a locality in the state of Tocantins (Fig. 1). The most peripheral hexagons from the biome's centroid presented a higher cumulative number of species, and the third distance class from the centroid presented the lowest cumulative richness (Fig. 2).

Regarding the shared species between the Cerrado and the neighbouring biomes, $15 \%$ were wide-ranging species, occurring often in more than two biomes. Most Cerrado species were shared with the Atlantic Forest (44\%), followed by the Amazon (15\%), the Caatinga (9\%), and the Pantanal (1\%). The proportion of TCS was $16 \%$. When we examined the species' distributions according to the Flora do Brasil Species List database, only 47 ( $5 \%$ from all species) were considered exclusive to the Cerrado. The estimated total richness for the cerrado was between 1,000 and 1,308 tree species (Tab. 1). Most hexagons that lacked samples were located in the ecotonal regions between the Cerrado and the adjacent biomes (Fig. 3).
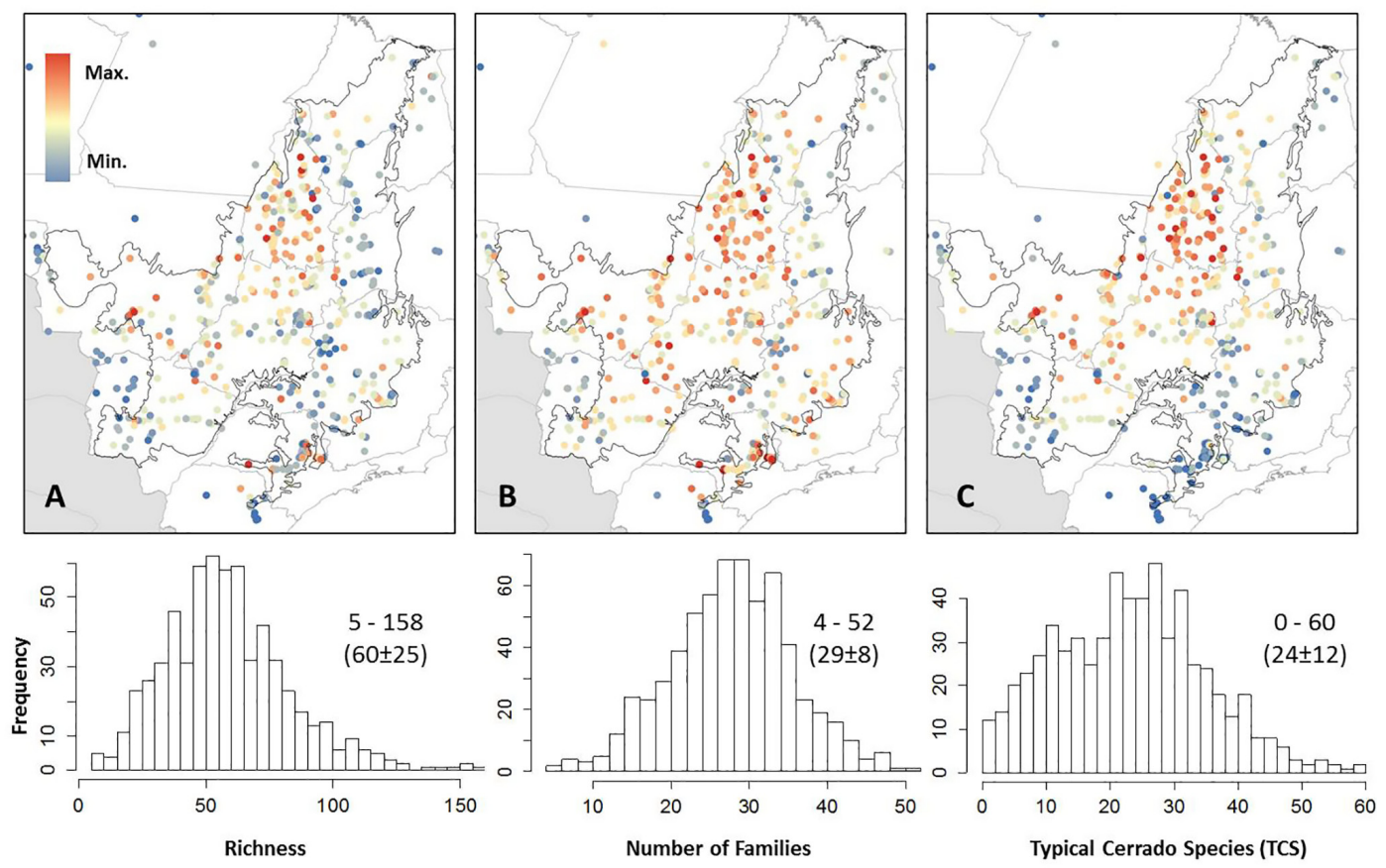

Figure 1. Frequency, minimum, maximum, average, and standard deviation of (A) species, (B) families, and (C) Typical Cerrado Species in the sites of inventories and rapid surveys in cerrado lato sensu in Cerrado biome, Brazil. Please see the PDF version for color reference.
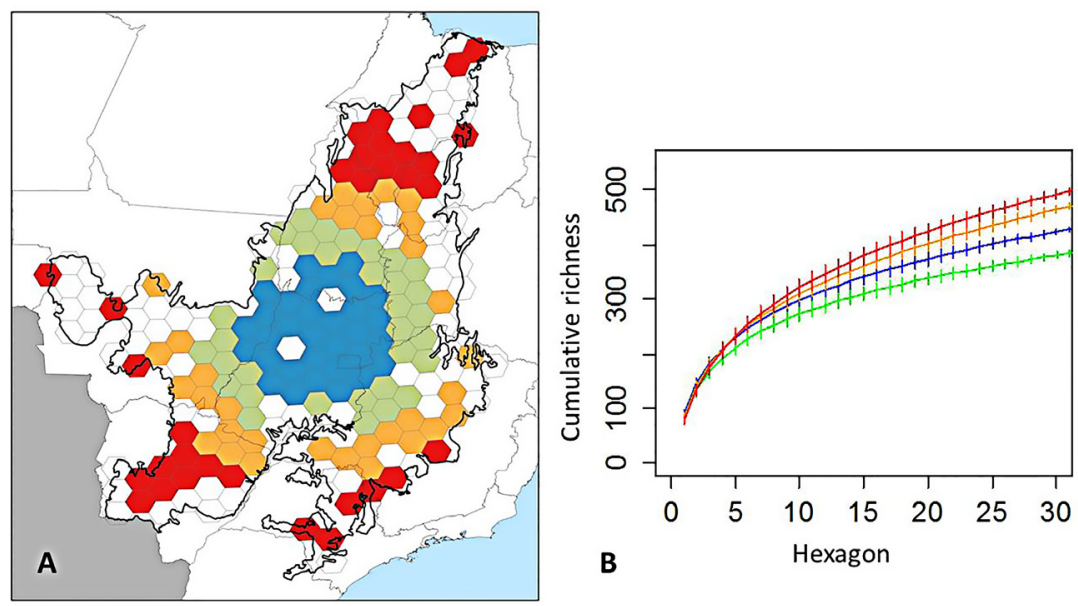

Figure 2. (A) Four distance classes to the Cerrado biome centroid. (B) Rarefaction curves of each distance class. The far distances have high cumulative richness. Please see the PDF version for color reference. 
Table 1. Tree species richness estimated for cerrado lato sensu, using four algorithms. The observed richness was obtained from 625 floristic inventories and rapid surveys in the Cerrado biome and disjunct cerrado areas in other biomes.

\begin{tabular}{|l|c|c|c|c|c|c|c|} 
& $\begin{array}{c}\text { Observed } \\
\text { richness }\end{array}$ & Chao I & Jackknifel & Jackknife2 & Bootstrap & Minimum \\
\hline Total & 909 & $1223 \pm 53$ & $1159 \pm 32$ & 1308 & $1019 \pm 19$ \\
\hline
\end{tabular}

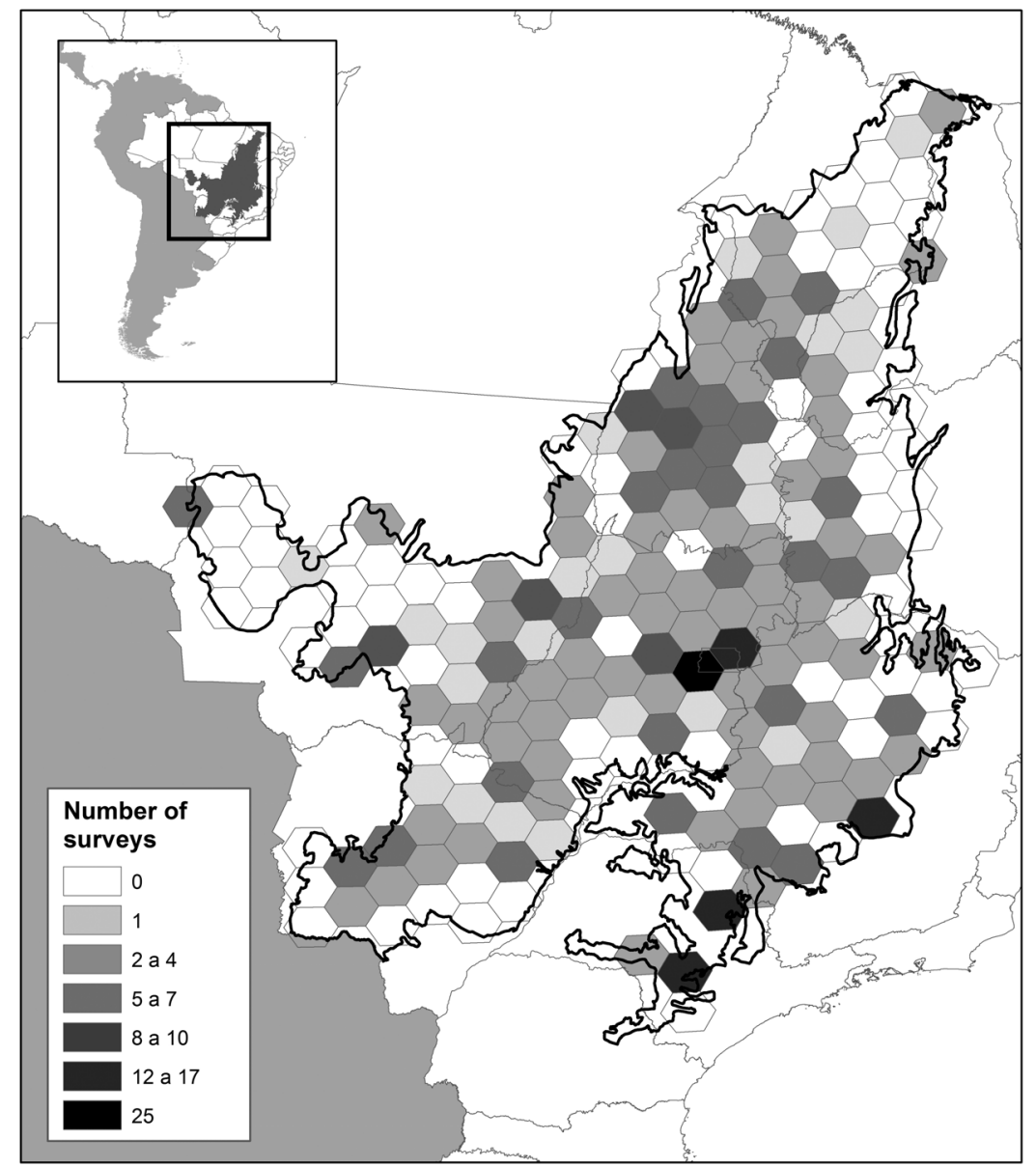

Figure 3. Number of floristic surveys per 1,000,000 ha hexagon in cerrado lato sensu inside Cerrado biome.

\section{Discussion}

The highest absolute richness values were observed in the central localities of the Cerrado, which suggests a pattern influenced by the mid-domain effect (Colwell \& Hurtt 1994), where the overlap of species' distributions results in a high number of species in the central portion of the Cerrado. This pattern has also been recorded for other taxonomic groups, such as for amphibians, reptiles, birds, and mammals (Diniz-Filho et al. 2009). However, in the transition zones between biomes, there is great opportunity for the appearance of species from other biomes, that produces a high beta diversity in ecotones, as was observed between the Caatinga and the Cerrado (Castro et al. 1998). These results are extremely important to direct conservation decisions and new biological surveys. These transition zones deserve renewed attention in the face of climate change (Allen \& Breshears 1998; Lafleur et al. 2010). Species from these zones might possess high physiological plasticity, and further investigative efforts in this regard might uncover important information to support biodiversity conservation actions. On the other hand, different edaphic conditions can impose a barrier for species dispersal under climate change events (Lafleur et al. 2010). Even though they present low local richness, ecotonal regions are an integral part of the Cerrado's biota. These zones, however, have undergone fewer studies per hexagon, and many times are not sampled at all. 
The locality with the highest richness presented 158 species, which is a high number in comparison to other areas, where it is rare to observe more than 120 species in a single locality (Ratter \& Dargie 1992). This number was recorded in a few sampling occasions while conducting 1-hectare sampling (Oliveira-Filho \& Ratter 2002; Ratter et al. 2011; Haidar et al. 2013) or floristic surveys (Batalha \& Martins 2007; Ratter et al. 2011). The high turnover of species among localities has been recorded several times in the Cerrado (Felfili et al. 1994; 2001; 2004; 2005b; Felfili \& Felfili 2001; Oliveira-Filho \& Ratter 2002; Bridgewater et al. 2004; Felfili \& Silva-Júnior 2005), and in present study it was no different, since only 154 species occurred in more than $10 \%$ of the localities. The 249 species with single records represent an important portion of the known richness of the biome. However, the majority of these species were distributed predominantly in other biomes, with marginal occurrence in the northern regions of the Cerrado, as described previously for the cerrados of Piauí and Maranhão states (Heringer et al. 1977).

In a study of 376 localities, Bridgewater et al. (2004) observed 951 tree and woody shrub species. The present study used the same database as a starting point, despite keeping only the tree species, which corresponded to 744 species from the original study by Bridgewater et al. (2004). After compiling data from other studies, we added 139 tree species to this database, while still foreseeing a need to add at least another 95 species, according to the most conservative richness estimator.

The ratio between the known tree and shrub species in a cerrado locality is approximately 1:3 (Batalha \& Martins 2007). In the savannas of Belize, in Central America, the proportion of non-trees in the vascular flora is $87 \%$ (Goodwin et al. 2013). Thus, in the Cerrado this ration maybe similar. In order to fill this information gap, we suggest the inclusion of species with smaller diameters in systematic inventories and surveys. The manual on permanent plots for the Cerrado (Felfili et al. 2005a) has been guiding phytosociological studies and inventories in the biome, with a focus on tree species. Even in regeneration sub-plots, only small tree species are included at best. The inclusion of a team of experts in herbs and shrubby species in inventories would represent a great advantage in allowing better understanding of the Cerrado's biodiversity; even more when considering that only $16 \%$ of the tree species recorded for the cerrado lato sensu are TCS, which are mainly found in the central portion of the biome (Fig. 4A). A far greater proportion of species is recorded for the shrub stratum (Mendonça et al. 2008). Moreover, several tree-like species found in a few localities do not grow higher than the shrub stratum in others (Ferri \& Coutinho 1958).

High rates of endemism and great threats to biodiversity are two criteria used in the definition of biodiversity hotspots (Myers et al. 2000). This status is extremely valuable to the Cerrado, where deforestation rates have reached alarming levels in the last few decades (Klink \& Machado 2005; IBAMA 2009; 2011). However, we found only $5 \%$ were endemic species when combining the TCS status and available information regarding distribution in the Flora do Brasil Species List database. Another 71 tree species are considered endemic to the Cerrado in the Flora do Brasil Species List. Some of these species were not present in our database. Others are widely found in other biomes, according to the records obtained from the SpeciesLink repository, which led us to disregard them as endemic. In order to understand the pattern of biodiversity distribution in the Cerrado, new studies covering shrubby and herbaceous species are extremely important, since these strata must contain a majority of the $44 \%$ endemism estimated for the Cerrado's plants (Myers et al. 2000).

The largest number of shared species between the Cerrado and the Caatinga are located in the transition zone between the two biomes (Fig. 4B). Thus, in some cases, it is not correct to affirm that these are accessory species, since they are equally important to the floristic composition of both biomes. The region with a higher presence of these species is the northern part of the Espinhaço mountain range, which is a region with several cerrado enclaves within the Caatinga. The term "accessory species" used by Rizzini (1963) and by Heringer et al. (1977) is artificial in ecological terms, since we don't know the species' origin. Besides, a species occurring in an area belongs to the local biota of that area (Castro et al. 1999).

Shared species between the Cerrado and the Atlantic Forest are located mainly in the Cerrado region of the state of São Paulo, in the southern portion of the Espinhaço range, and between these two regions (Fig. 4C). The cerrado vegetation in São Paulo state is part of the Southern Biogeographical Region, which is greatly influenced by the Atlantic Forest (Françoso 2014). In the predominantly high altitude field formations of the Espinhaço mountain range, vegetation is subjected to very different climatic conditions from those found in the ombrophilous forests below. Several of these high altitude fields border the Cerrado biome, and because the altitude defines similar climatic conditions between the two regions, a high number of species common to both of them is to be expected. In this way, we once again observe that shared species are equally important to both biomes.

The proportion of species shared with the Atlantic Forest is three times higher than the proportion shared with the Amazon, in spite of the fact that the longest border between these biomes is found between the Cerrado and the Amazon. This same pattern has been described by Rizzini (1963) and by Heringer et al. (1977), who have quantified the number of genera found in other Brazilian biomes. They found a higher proportion of genera shared with the Atlantic Forest (80\%) than with the Amazon (77\%) (Heringer et al. 1977). Nevertheless, new surveys of information gaps in the Amazon (Sousa-Baena et al. 
2014) can certainly contribute to changes in that proportion. Also, considering the low sampling effort in the Amazon, we could not identify a distribution pattern for the shared species richness between the Cerrado and the Amazon (Fig. 4D).

When comparing the present study with previous ones regarding the number of cerrado families (Rizzini 1963; Heringer et al. 1977; Castro et al. 1999; Bridgewater et al. 2004), including local studies (Batalha \& Martins 2007), the same families appear to be the most numerous, but not necessarily in the exact same order. The most numerous genera presented here (Miconia, Myrcia, Eugenia and Byrsonima) displayed a great variation in number of species when compared to the compilation by Heringer et al. (1977), in which Byrsonima was the richest genus ( $\mathrm{n}=22$ ), followed by Myrcia $(\mathrm{n}=18)$, Kielmeyera $(\mathrm{n}=16)$, Miconia $(\mathrm{n}=15)$ and Annona $(\mathrm{n}=11)$. Differences are even greater when compared to the data presented by Rizzini (1963), in which the most representative genera were Miconia and Bombax ( $\mathrm{n}=11)$, Byrsonima $(\mathrm{n}=10)$, Annona and Aspidosperma ( $\mathrm{n}=9)$, and Cassia, Myrcia and Qualea $(\mathrm{n}=8)$.
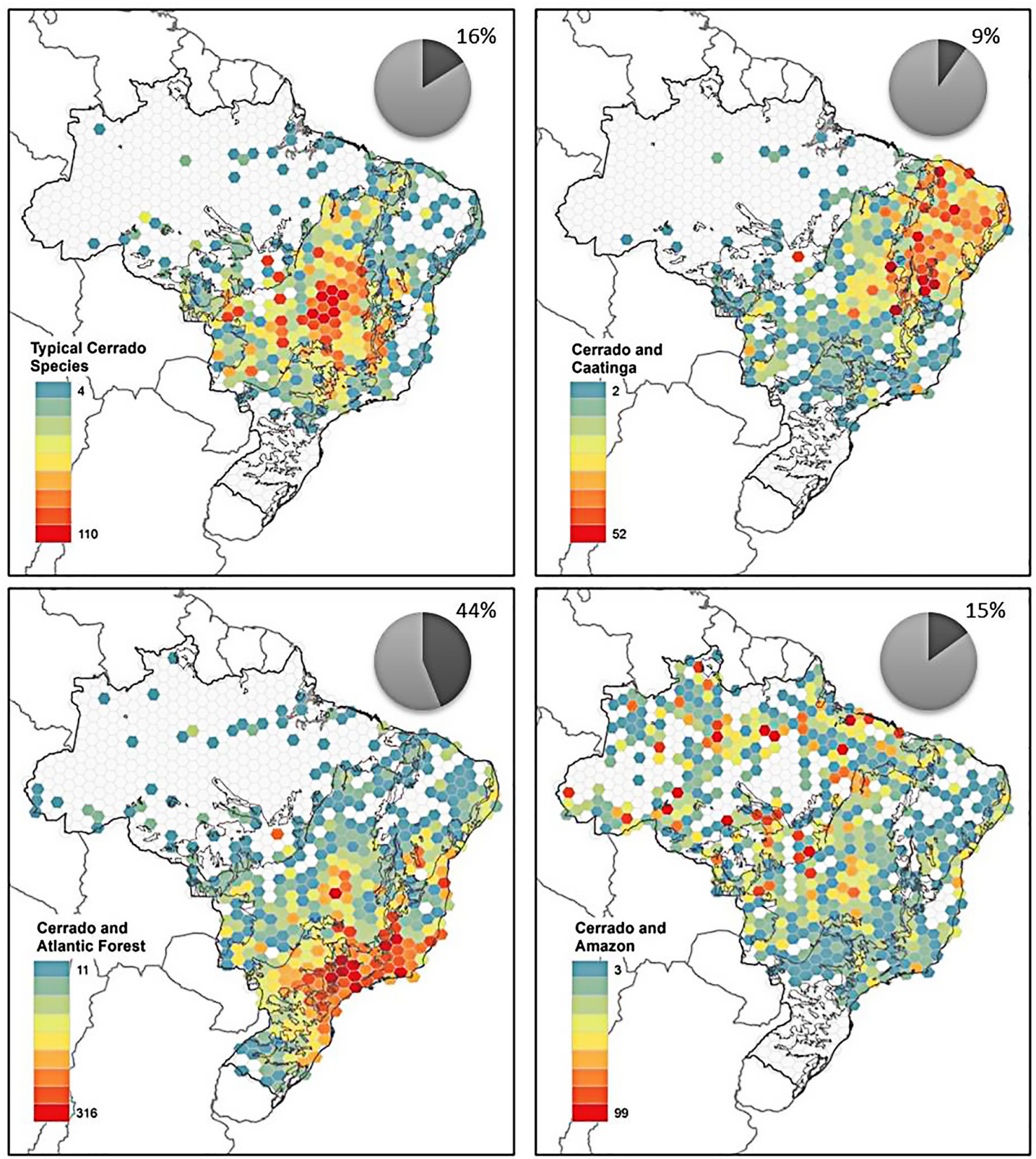

Figure 4. Number of species by 1,000,000 ha hexagon for (A) Typical Cerrado Species, species shared between the Cerrado and (B) Caatinga, (C) Atlantic Forest, and (D) Amazon Forest. The pie charts indicate the proportion of shared species between the Cerrado and the specific biome in 625 floristic surveys in cerrado lato sensu. The widely distributed species correspond to $15 \%$ of all 907 tree species, and only one per cent of the species are shared by the Cerrado and Pantanal. Please see the PDF version for color reference. 
Considering all of the species found in the cerrado, the Vochysiaceae family does not have the highest number of species. However, when considering only the TCS, it is the second family in number of species, as was observed by Rizzini (1963). Moreover, this family is one of the most frequent in the Cerrado, due to the wide-ranging species Qualea parviflora, Q. grandiflora, and Q. multiflora (Oliveira-Filho \& Ratter 2002). Our observations were no different, and we also certified that these species are some of the most frequent.

When comparing the ecological parameters of cerrado stricto sensu in three localities, Ferri \& Coutinho (1958) suggested that there is a uniformity across this physiognomy, due to a marked presence of wide-ranging species. One hundred and twenty species are considered characteristic to the biome (Ratter \& Dargie 1992; Ratter et al. 1996; 2003; Bridgewater et al. 2004). Using the same parameters to review the dominant species in the Cerrado (according to Bridgewater et al. 2004), we found 20 species less, probably due sample addition and increased knowledge of the Cerrado flora.

Some families presented a low number of species, and 12 of 76 families presented only one species each. This feature of the cerrado vegetation is one of the reasons why a high rate of endemism is associated with this tree vegetation (Batalha $\&$ Martins 2007). However, this is not acceptable, since most of these families are characteristic of other biomes and other formations, only occasionally occurring in the cerrado. Families and genera with only one species must have relict distributions, with low diversification in central Brazil, or must be a product of recent colonization events, as observed in some legume species (Simon et al. 2009; 2011).

In our study, we observed high richness (907 tree species) and beta diversity for the tree species in the Cerrado, as well as a great number of families and genera, many containing a single species. The Atlantic Forest has the greatest number of shared flora with the Cerrado. The number of endemic species observed was lower than that estimated for the Cerrado's flora, but the highest proportion of endemic species is possibly found in other life-forms, such as herbs, lianas, shrubs, and sub-shrubs, and it is crucial to include these species in inventories and floristic surveys. In order to guide new studies and help supplement the knowledge of the Cerrado's flora, we identified sampling gaps, located mainly in ecotonal regions, which are responsible for the greatest part of the species recorded in studies of the Cerrado.

\section{Acknowledgments}

We would like to thanks the Coordination for the Improvement of Higher Level Personnel (CAPES), National Council of Scientific and Technological Development (CNPq) and Science Without Borders Program for the study scholarships granted to RDF. Thanks to CNPq for the productivity scholarship granted to RBM, and for financial support (CNPq: 457431/20012-1). Thanks to O Boticário Foundation and to the Cerrado Agroecological Center for funding and supporting the fieldwork. To the ComCerrado Network for providing access to laboratory infrastructure.

\section{References}

Amaral AG. 2015. A Flora herbáceo-arbustiva do Cerrado: Aspectos ecológicos e fitogeográficos. Brasília, Universidade de Brasília. doi: 10.1007/s13398-014-0173-7.2.

Batalha MA, Martins FR. 2007. The vascular flora of the cerrado in Emas National Park (Central Brazil): a savanna flora summarized. Brazilian Archives of Biology and Technology 50: 269-277.

Boulinier T, Nichols JD, Sauer JR, Hines JE, Pollock KH. 1998. Estimating species richness: the importance of heterogeneity in species detectability. Ecology 79: 1018-1028.

Bridgewater S, Ratter JA, Ribeiro JF. 2004. Biogeographic patterns, Betadiversity and dominance in the cerrado biome of Brazil. Biodiversity and Conservation 13: 2295-2318.

Castro AAJF, Martins FR, Fernandes AG. 1998. The woody flora of cerrado vegetation in the state of Piaui, northeastern Brazil. Edinburgh Journal of Botany 55: 455-472.

Castro AAJF, Martins FR, Tamashiro JY, Shepherd GJ. 1999. How rich is the flora of Brazilian Cerrados? Annals of the Missouri Botanical Garden 86: 192-224.

Clements FE, Shelford V. 1939. Bio-ecology. New York/ London, John Wiley \& Sons/ Chapman \& Hall.

Colwell RK, Hurtt GC. 1994. Nonbiological gradients in species richness and a spurious rapoport effect. The American Naturalist 144: 570-595.

Coutinho LM. 2006. O conceito de bioma. Acta Botanica Brasilica 20: 13-23.

Di Minin E, Moilanen A. 2014. Improving the surrogacy effectiveness of charismatic megafauna with well-surveyed taxonomic groups and habitat types. Journal of Applied Ecology 51: 281-288.

Diniz-Filho JAF, Binni LM, Oliveira G. et al. 2009. Macroecologia, biogeografia e áreas prioritárias para conservação no cerrado. Oecologia Brasiliensis 13: 470-497.

Eiten G. 1972. The Cerrado vegetation of Brazil. The Botanical Review 38: 201-341.

ESRI - Environmental Systems Research Institute. 2011. ArcGIS Desktop. Redlands, ESRI.

Felfili JM, Silva-Júnior MC, Sevilha AC. et al. 2004. Diversity, floristic and structural patterns of cerrado vegetation in Central Brazil. Plant Ecology 175: 37-46.

Felfili JM, Filgueiras TS, Haridasan MH, Silva-Júnior MC, Mendonça RC, Rezende AV. 1994. Projeto biogeografia do bioma Cerrado: vegetação e solos. Cadernos de Geociências 12: 75-167.

Felfili JM, Carvalho FA, Haidar RF. 2005a. Manual para o monitoramento de parcelas permanentes nos biomas Cerrado e Pantanal. Brasília, Universidade de Brasília.

Felfili JM, Silva-Júnior MC. 2005. Diversidade alfa e beta no cerrado sensu stricto, Distrito Federal, Goiás, Minas Gerais e Bahia. In: Scariot A, Sousa-Silva JC, Felfili J. (eds.) Cerrado: ecologia, biodiversidade e conservação. Brasília, Ministério do Meio Ambiente. p. 141-154.

Felfili JM, Sousa-Silva JC, Scariot A. 2005b. Biodiversidade, ecologia e conservação do Cerrado: avanços no conhecimento. In: Scariot A, Sousa-Silva JC, Felfili J. (eds.) Cerrado: ecologia, biodiversidade e conservação. Brasília, Ministério do Meio Ambiente. p. 25-44.

Felfili MC, Felfili JM. 2001. Diversidade alfa e beta no cerrado sensu stricto da Chapada Pratinha, Brasil. Acta Botanica Brasilica 15: 243-254.

Ferri MG, Coutinho LM. 1958. Contribuição ao conhecimento da ecologia do cerrado. Estudo comparativo da economia d'água de sua vegetacao, em Emas (Est. de São Paulo), Campo Grande (Est. de Mato Grosso) e 
Goiânia (Est. de Goiás). Boletim da Faculdade de Filosofia, Ciências e Letras, Universidade de São Paulo. Botânica 12: 103-150.

Forni-Martins ER, Martins FR. 2000. Chromosome studies on Brazilian cerrado plants. Genetics and Molecular Biology 23: 947-955.

Françoso R. 2014. Padrões biogeográficos e composição das comunidades arbóreas do Cerrado brasileiro. Brasília, Universidade de Brasília.

Goodwin Z, Lopez G, Stuart N, et al. 2013. Radiocarbon and DNA evidence for a pre-Columbian introduction of Polynesian chickens to Chile. Phytotaxa 101: 1-119.

Haidar RF, Dias R, Felfili JM. 2013. Mapeamento das regiões fitoecológicas e inventário florestal do estado do Tocantins. Palmas, Governo do Estado do Tocantins. http: //www.seplan.to.gov.br/Arquivos/ download/ZEE/TO_Rel_Mapeamento_Regioes_Fitoecologicas_Inventario_Florestal/Rel_Inv_Florestal_TO.pdf.

Heringer EP, Barroso GM, Rizzo JA, Rizzini CT. 1977. A flora do Cerrado. In: Ferri MG. (ed.) IV Simpósio sobre o Cerrado. São Paulo, Editora da Universidade de São Paulo. p. 211-232.

Hoffmann WA, Silva-Júnior ER. 2005. Seasonal leaf dynamics across a tree density gradient in a Brazilian savanna. Functional Ecology 19: 932-940.

IBAMA - Instituto Brasileiro do Meio Ambiente e dos Recursos Naturais Renováveis. 2009. Relatório técnico de monitoramento do desmatamento no bioma Cerrado, 2002 a 2008: dados revisados. Brasília, IBAMA.

IBAMA - Instituto Brasileiro do Meio Ambiente e dos Recursos Naturais Renováveis. 2011. Monitoramento do desmatamento nos biomas brasileiros por satélite. Brasília, IBAMA.

IBGE - Instituto Brasileiro de Geografia e Estatística. 2004. Mapa de Biomas do Brasil. Escala 1: 5.000.000. http: //www.ibge.gov.br/ home/presidencia/noticias/21052004biomas.shtm.

Klink CA, Machado RB. 2005. Conservation of the Brazilian Cerrado. Conservation Biology 19: 707-713.

Lombard AT, Cowling RM, Pressey RL, Rebelo AG. 2003. Effectiveness of land classes as surrogates for species in conservation planning for the Cape Floristic Region. Biological Conservation 112: 45-62.

Lomolino MV, Riddle BR, Brown JH. 2006. Biogeography. 3rd. edn. Sunderland, Sinauer Associates.

Machado RB, Aguiar LMS, Castro AAJF, Nogueira CC, Ramos-Neto MB. 2008. Caracterização da fauna e flora do Cerrado. In: Faleiro FG, Farias-Neto AL. (eds.) Savanas: desafios e estratégias para o equilíbrio entre sociedade, agronegócio e recursos naturais. Brasília, Embrapa. p. 284-300.

Méio BB, Freitas CV, Jatobá L, Silva MEF, Ribeiro JF, Henriques RPB. 2003. Influência da flora das florestas Amazônica e Atlântica na vegetação do cerrado sensu stricto. Revista Brasileira de Botânica 26: $437-444$

Mendonça RC, Felfili JM, Walter BMT, et al. 2008. Flora vascular do bioma Cerrado: checklist com 12.356 espécies. In: Sano S, Almeida S, Ribeiro J, (eds.) Cerrado: ecologia e flora. Brasília, Embrapa Informação Tecnológica. p. 423-1279.

Myers N, Mittermeier RA, Mittermeier CG, Fonseca GAB, Kent J. 2000. Biodiversity hotspots for conservation priorities. Nature 403: 853-858
Oliveira-Filho AT, Ratter JA. 2002. Vegetation Physiognomies and Woody Flora of the Cerrado Biome. In: Oliveira PS, Marquis RJ. (eds.) The Cerrados of Brazil: ecology and natural history of a neotropical savanna. New York, Columbia University Press. p. 93-120.

Oliver I, Holmes A, Dangerfield JM, et al. 2004. Land systems as surrogates for biodiversity in conservation planning. Ecological Applications 14: 485-503.

Ratter JA, Bridgewater S, Ribeiro JF, et al. 2011. Analysis of the floristic composition of the Brazilian cerrado vegetation IV: Presentation of a Revised Data-Base of 367 Areas. Conservation and Management of the Biodiversity of the Cerrado Biome 1-85. http: //cerrado.rbge. org.uk/cerrado/download/download.php.

Ratter JA, Bridgewater S, Atkinson R, Ribeiro JF. 1996. Analysis of the floristic composition of the Brazilian cerrado vegetation II: Comparison of the woody vegetation of 98 areas. Edinburgh Journal of Botany 53: 153.

Ratter JA, Bridgewater S, Ribeiro JF. 2003. Analysis of the floristic composition of the Brazilian Cerrado vegetation III: Comparison of the Woody Vegetation of 376 Areas. Edinburgh Journal of Botany 60: 57-109.

Ratter JA, Dargie TCD. 1992. An analysis of the floristic composition of 26 cerrado areas in Brazil. Edinburgh Journal of Botany 49: 235.

Ribeiro JF, Walter BMT. 2008. As principais fitofisionomias do bioma Cerrado. In: Sano SM, Almeida SP, Ribeiro JF. (eds.) Cerrado: ecologia e flora. Brasília, Embrapa. p. 151-212.

Rizzini CT. 1963. A flora do Cerrado. In: Ferri MG. (ed.) Simpósio sobre o Cerrado. São Paulo, Editora da Universidade de São Paulo. p. 127-177.

Silva JMC, Bates JM. 2002. Biogeographic Patterns and Conservation in the South American Cerrado: A Tropical Savanna Hotspot. BioScience 52: 225-234.

Silva LCR, Sternberg L, Haridasan M, Hoffmann WA, Wilhelm FM, Franco AC. 2008. Expansion of gallery forests into central Brazilian savannas. Global Change Biology 14: 2108-2118.

Silva LCR, Haridasan M, Hoffmann WA, Sternberg LSL, Franco AC. 2010. Not all forests are expanding over central Brazilian savannas. Plant and Soil 333: 431-442.

Simon MF Grether R, Queiroz LP, et al. 2009. Recent assembly of the Cerrado, a neotropical plant diversity hotspot, by in situ evolution of adaptations to fire. Proceedings of the National Academy of Sciences of the United States of America 106: 20359-20364.

Simon MF, Grether R, Queiroz LP, et al. 2011. The evolutionary history of Mimosa (Leguminosae): toward a phylogeny of the sensitive plants. American Journal of Botany 98: 1201-1221

Sousa-Baena MS, Garcia LC, Peterson AT. 2014. Completeness of digital accessible knowledge of the plants of Brazil and priorities for survey and inventory. Diversity and Distributions 20: 369-381.

Stoms D, Comer P, Crist P, Grossman D. 2005. Choosing surrogates for biodiversity conservation in complex planning environments. Journal of Conservation Planning 1: 1-17.

Walter BMT, Guarino EDSG. 2006. Comparação do método de parcelas com o 'levantamento rápido' para amostragem da vegetação arbórea do Cerrado sentido restrito. Acta Botanica Brasilica 20: 285-297. 